\title{
Cegah Stunting Pada Masa Pandemi Covid-19 dengan Pembentukan Srikandi PMBA
}

\author{
Rahayu Widaryanti*1, Lenna Maydianasari2, Melani Maranressy ${ }^{3}$ \\ 1,2, 3 Program Studi Kebidanan Program Sarjana Fakultas Imu Kesehatan Universitas Respati Yogyakarta \\ *e-mail: rwidaryanti@respati.ac.id1, lenna@respati.ac.id², 19180010@respati.ac.id³
}

\begin{abstract}
Abstrak
Pada masa pandemic COVID-19 layanan kesehatan ibu dan anak khususnya pada 1000 hari pertama kehidupan (HPK) menjadi terhambat. Status kesehatan yang tidak dipantau dalam waktu yang lama dapat menimbulkan masalah baru pada ibu dan anak. Untuk itu pengabdi membentuk Srikandi PMBA yang merupakan kader kesehatan untuk kembali mengaktifkan posyandu sehingga pelayanan kesehatan di masyarakat kembali berjalan. Metode pelaksanaan kegiatan yang digunakan berupa partisipasi masyarakat yaitu pendidikan masyarakat, pembentukan srikandi PMBA, pendampingan, serta role play. Hasil dari kegiatan ini adalah terdapat peningkatan pengetahuan kader tentang pemberian makan bayi dan anak serta tehnik komunikasi dan konseling sebanyak 45 point. Kegiatan selanjutnya yaitu pemantauan tumbuh kembang menggunakan KPSP yang diikuti oleh 8 balita dengan hasil 75\% sesuai dan $25 \%$ meragukan. Selain pemeriksaan tumbuh kembang Srikandi PMBA juga melakukan edukasi PMBA dan menjadi motor gerakan kebun gizi dengan cara memanfaatkan lahan pekarangan untuk menanam sayur untuk memenhi kebuthan ruumah tangga. Kegiatan ini penting dilakukan mengingat masih ada balita yang mengalami masalah gizi karena kurang nya pengetahuan tentang menu yang tepat untuk anak.
\end{abstract}

Kata Kunci : Covid-19, Srikandi PMBA, Stunting

\begin{abstract}
During the COVID-19 pandemic, maternal and child health services, especially in the first 1000 days of life, were hampered. Health status that is not monitored for a long time can cause new problems for both mother and child. For this reason, the servants form Srikandi IYCF who are health cadres to reactivate the posyandu so that health services in the community can resume running. The method of implementing activities used is in the form of community participation, namely community education, formation of IYCF heroines, mentoring, and role play. The result of this activity is that there is an increase in the knowledge of cadres about feeding babies and children as well as communication and counseling techniques by as much as 45 points. The next activity was monitoring growth and development using developmental pre-screening questionnaire, which was followed by 8 toddlers with results that were $75 \%$ appropriate and $25 \%$ doubtful. In addition to examining the growth and development of Srikandi IYCF also conducts IYCF education and becomes the motor of the nutrition garden movement by utilizing yard land to plant vegetables to fulfill household needs. This activity is important to do considering there are still toddlers who experience nutritional problems due to lack of knowledge about the right menu for children.
\end{abstract}

Keywords: Covid-19, Srikandi IYFC, Stunting

\section{PENDAHULUAN}

Di Indonesia, sekitar 37\% (hampir 9 juta) anak balita mengalami stunting, Indonesia adalah Negara kelima dengan stunting terbesar. Persentase balita sangat pendek dan pendek usia 0-59 bulan di Indonesia tahun 2018 adalah 11,5\% dan 19,3\%. Kondisi ini meningkat dari tahun sebelumnya yaitu persentase balita usia 0-59 bulan sangat pendek sebesar 9,8\% dan balita pendek sebesar 19,8\% (Kemenkes, 2018). Di Daerah Istimewa Yogyakarta angka kejadian stunting juga masih cukup tinggi yaitu 27, 2\%(Indonesia, 2020). Di Kabupaten Sleman prevalensi status gizi balita pendek dan sangat pendek pada tahun 2017 mengalami peningkatan $0,18 \%$ dibandingkan tahun 2016 yaitu dari 11,81\% menjadi 11,99\%. Prevalensi status gizi balita pendek dan sangat pendek di wilayah kerja Puskesmas Kalasan merupakan tertinggi kedua setelah Kecamatan Godean yaitu 20,71\% (Dinkes, 2020). Dari Hasil penelitian yang dilakukan di Puskesmas Kalasan pada tahun 2019 diketahui bahwa 47\% balita yang mengalami stunting 
dikarenakan praktik pemberian PMBA yang tidak tepat. Sebagian besar ibu mulai memberikan MP ASI pada anaknya mulai usia 5 bulan, makanan yang sering diberikan adalah pisang lumat dan bubur beras. Pemberian MP ASI harus memperhatikan Angka Kecukupan Gizi (AKG) yang di anjurkan berdasarkan kelompok umur dan tekstur makanan yang sesuai perkembangan usia balita. terkadang orang tua memberikan MP ASI sebelum usia 6 bulan, padahal usia tersebut kemampuan pencernaan bayi belum siap menerima makanan tambahan akibatnya banyak yang mengalami diare (Widaryanti, 2019).

Faktor yang menyebabkan Stunting di Kabupaten Sleman antara lain kurangnya konseling antara petugas dengan keluarga pasien selama masa kehamilan, kelahiran dan masa bayi, sehingga keluarga terlambat dalam memutuskan dan mencari bantuan kesehatan. Pendidikan masyarakat yang kurang, sehingga kurang dapat mengenali adanya gangguan-gangguan kesehatan pada ibu dan bayi. Keterbatasan jumlah tenaga kesehatan di masyarakat menyebabkan kurangnya intensitas konseling maupun pendidikan kesehatan bagi masyarakat. Hal ini dapat di atasi dengan pemberdayaan anggota masyarakat menjadi kader kesehatan. Keuntungan kader kesehatan di masyarakat lebih memudahkan menyampaikan informasi kesehatan karena kedekatan secara psikologis maupun waktu (Dinkes, 2020). Hasil penelitian Subagyo (2010) juga menyatakan bahwa kemampuan kader mempunyai hubungan yang signifikan dengan keberhasilan program posyandu. Penelitian yang dilakukan Rahmawati, Madanijah, Anwar, and Kolopaking (2019) konseling yang dilakukan oleh kader mampu meningkatkan nilai praktik PMBA pada ibu bayi dan anak usia 6-24 bulan, khususnya tentang konsumsi lauk hewani, bentuk kekentalan atau tekstur dan variasi makanan.

Pandemi Covid-19 merupakan salah satu bencana non alam yang mempunyai efek besar terhadap semua bidang kehidupan termasuk kesehatan. Dimasa ini praktik pemberian makan bayi dan anak yang tepat dapat membantu menjaga ketahanan keluarga. Bayi dan balita merupakan salah satu kelompok yang rentan terdampak sehingga memerlukan perhatian lebih. Pelayanan regular di Pusksmas banyak yang belum optimal karena petugas masih berfokus terhadap penanggulangan Covid-19, selain itu kegiatan posyandu di masyarakat juga terhenti sehingga menyebabkan akses kesehatan bayi dan balita terputus. Salah satu cara agar kesehatan bayi dan balita tetap terjaga dapat dilakukan dengan praktik pemberian makan bayi dan balita secara tepat. Pemberian ASI menjadi pilihan makanan yang paling aman bagi bayi ketika adanya keterbatasan akses makanan maupun pelayanan kesehatan. ASI memiliki kandungan antibodi yang tinggi sehingga meningkatkan daya tahan tubuh bayi di masa pandemik. Selain itu pemberian ASI dapat mengurangi pengeluaran belanja keluarga, dimana dalam masa pandemi banyak keluarga yang mengalami penurunan pendapatan finansial akibat pembatasan sosial berskala besar (Sakti, 2018).

Kader posyandu mempunyai peran penting dalam keberhasilan program PMBA di masyarakat, karena kader merupakan orang yang terdekat dengan masyarakat. Namun belum semua kader posyandu pernah mengikuti pelatihan PMBA, dari hasil penelitian Rahayu Widaryanti and Rahmuniyati (2019) setiap dusun baru satu kader yang dilatih PMBA, namun belum semua kader mempraktikkan hasil pelatihan ke masyarakat. Banyak kendala yang dihadapi oleh kader dalam mempraktikkan PMBA kemasyarakat seperti jumlah kader PMBA yang masih kurang serta persebaran yang belum merata, dana untuk melakukan pelatihan PMBA yang terbatas dan refresing materi masih terbatas, sarana dan prasarana untuk melakukan konseling kepada masyarakat masih kurang, belum tersedia formulir untuk mendokumentasikan hasil konseling kader PMBA kepada masyarakat, serta tidak adanya monitoring dan evaluasi seccara berkala dari pihak puskesmas (Rahayu Widaryanti, 2019a). Paran kader posyandu untuk mempromosikan PMBA dalam kondisi darurat merupakan salah satu upaya yang tepat untuk tetap menjaga kebutuhan nutrisi bayi dan balita pada masa pandemi Covid-19. Namun sayangnya belum banyak kader yang paham mengenai manajeemen PMBA dalam kondisi normal maupun 
bencana. Penelitian yang dilakukan Rahayu Widaryanti (2019b) diperoleh data hanya $16 \%$ kader posyandu yang memahami tentang manajemen PMBA dalam kondisi darurat.

Srikandi PMBA merupakan sebutan bagi kader yang medampingi masyarakat dalam periode 1000 HPK. Srikandi merupakan sosok perempuan tangguh, sehingga pengabdi mengadopsi sosok ini dan menerapkan dalam masyarakat yang akan berjuang dengan tangguh untuk mengkampanyekan program 1000 HPK (hari pertama kehidupan) mulai dari pendampingan kehamilan, IMD, pendampingan pemberian ASI eksklusif 6 bulan dan dilanjutkan 2 tahun serta pendampingan dalam pemberian MP ASI secara tepat. Srikandi PMBA merupakan kader kesehatan yang dilatih tentang materi pemberian makan bayi dan anak (IMD, ASI Eksklusif, MP ASI, pemberian asi hingga dua tahun) dan akan mengaplikasikan hasil pelatihannya dengan cara mendampingi masyarakat khususnya ibu yang memiliki bayi dan balita dalam praktik menyusui, pemberian MP ASI serta pengoptimalan lahan pekarangan untuk dijadikan kebun gizi. Pembentukan Srikandi PMBA dapat membantu dalam menurunkan masalah gizi di masyarakat.

\section{METODE}

Kegiatan ini dilaksanakan mulai bulan September sampai dengan November 2020, di Dusun Sentikan, Karangnongko, Tirtomartani, Kalasan, Sleman, DIY. Jumlah peserta yang menjadi Srikandi PMBA berjumah 8 kader. Metode pelaksanaan kegiatan yang digunakan berupa partisipasi masyarakat yaitu pendidikan masyarakat, pembentukan srikandi PMBA, pendampingan, serta role play, adapun rincian nya sebagai berikut:

Tabel 1. Kegiatan Pelaksanaan Program

\begin{tabular}{lll}
\hline No & Metode & Kegiatan \\
\hline 1 & Pendidikan & Memberikan pengetahuan tentang manajemen laktasi, manajemen \\
& Masyarakat & $\begin{array}{l}\text { PMBA, tehnik konseling dan komunikasi efektif, serta pemanfaatan } \\
\text { lahan pekarangan untuk kebun gizi }\end{array}$ \\
2 & Pendampingan & $\begin{array}{l}\text { Pendampingan konseling nutrisi pada 1000 hari pertama } \\
\text { kehidupan seperti konseling gizi pada ibu hamil, IMD, konseling } \\
\end{array}$ \\
& $\begin{array}{l}\text { ASI eksklusif, pemberian MP ASI, serta pamantauan tumbang oleh } \\
\text { Srikandi PMBA }\end{array}$ \\
& Memberikan cara membuat MP ASI rumahan dengan bahan lokal, \\
& menanam sayuran menggunakan vertical gaden tobs sehingga tetap \\
& & \\
& &
\end{tabular}

\section{HASIL DAN PEMBAHASAN}

Kegiatan pengabdian kepada masyarakat dengan judul pembentukan Srikandi PMBA di Dusun Sentikan, Karangnongko, Tirtomartani, Kalasan, Sleman diawali dengan koordinasi dengan pemangku kebijakan pada bulan Agustus 2020, selanjutnya menyusun buku petunuk Srikandi PMBA. Kegiatan pelatihan dan pembentukan Srikandi PMBA dilaksanakan pada hari Sabtu, 19 September 2020 dengan jumlah peserta 8 kader posyandu. Kegiatan ini dilaksanakan pada masa adaptasi kebiasaan baru, sehingga pengabdi melakukan protokol ksehatan seperti melakukan cuci tangan menggunakan handsanitazer sebelum memasuki ruangan, menggunakan masker serta jaga jarak. Kegiatan selanjutnya peserta mengisi daftar hadir dengan bolpoint sendirisendiri sehingga mengurangi risiko kontak dengan peserta lainnya. Peserta selanjutnya mengisi lembar pre-test yang disediakan dengan tujuan untuk mengetahui tingkat pengetahuan kader sebelum mendapatkan pelatihan mengenai pemberian makan bayi dan anak. Pemberian materi tahap 1 dilaksanakan selama 6 jam, adapun rincian materi berupa inisiasi menyusu dini, ASI eksklusif, memberikan ASI hingga 2 tahun, cara penyapihan, tehnik menyusui yang benar, 
masalah menyusui dan cara mengatasi serta tehnik konseling efektif. Setelah selesai pemberian materi maka dilakukan post test yang bertujuan untuk mengetahui peningkatan pengetahuan yang di dapat oleh peseta. Berikut adalah tabel hasil test kemampuan dasar peserta pelatihan PMBA yang diuji pada awal dan akhir kegiatan pengabdian:

Tabel 1. Hasil analisis nilai pre test dan post test

Tingkat Pengetahuan Tentang Pemberian Makan Bayi dan Anak serta tehnik komunikasi dan konseling

\begin{tabular}{lc}
\hline Pretest & 48,75 \\
Posttest & 93,75 \\
$\Delta$ Pretest-Posttest & 45 \\
\hline
\end{tabular}

Berdasarkan tabel 1 diketahui bahwa sebelum pemberian materi tingkat pengetahuan kader tentang PMBA dan tehnik konseling rata-rata 48,75 poin, setelah mengikuti pmberian materi maka nilai rata-rata post test adalah $93,75 \%$ atau naik sebanyak 45 poin. Soal penilaian pre test dan post test sebanyak 10 soal, berikut analisis kenaikan kemampuan peserta berdasarkan analisis butir soal.

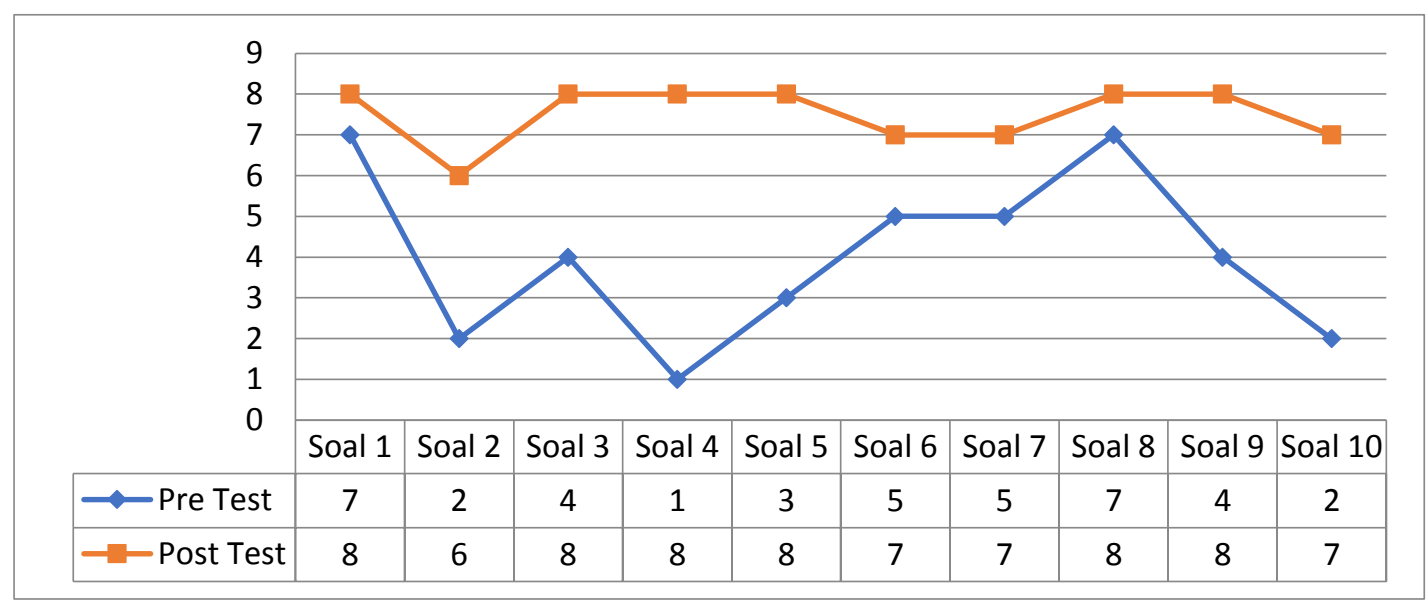

Gambar 1. Hasil test kemampuan dasar peserta pelatihan PMBA yang diuji pada awal dan akhir kegiatan pengabdian.

Setelah kegiatan pelatihan dan pembentukan Srikandi PMBA maka kegiatan selanjutnya yaitu menginisiasi gerakan sukses ASI eksklusif, MP ASI, bayi sehat serta pemanfaatan tanaman pekarangan sebagai kebun gizi. Harapan dari program ini adalah masyarakat dapat mencapai derajat kesehatan bayi dan balita secara optimal.

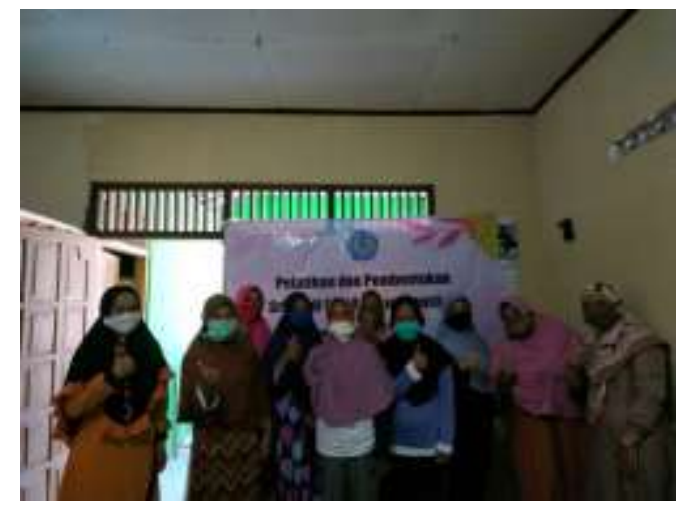

Gambar 2. Pelatihan dan Pembentukan Srikandi PMBA 


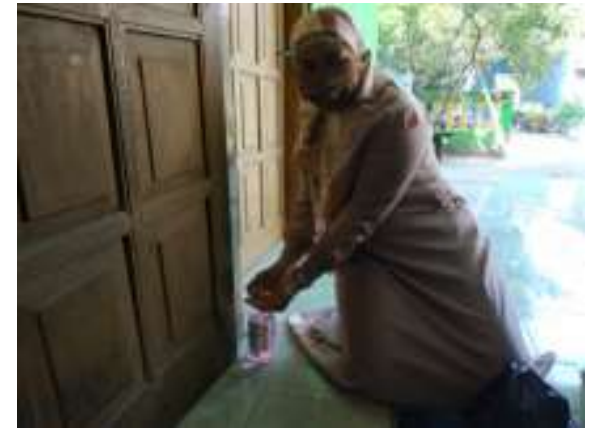

(a)

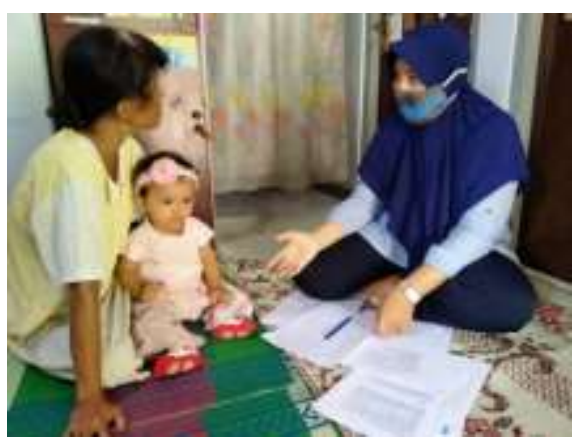

(c)

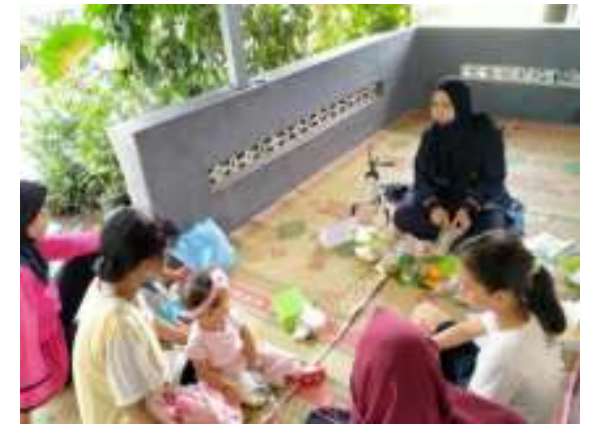

(b)

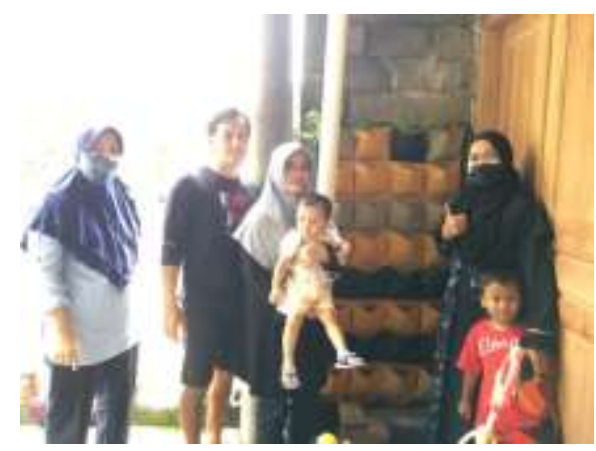

(d)

Gambar 3. Kegiatan Pelatihan dan Pembentukan Srikandi PMBA (a) Penerapan protokol kesehatan, (b) Edukasi PMBA, (c) Pemantauan tumbuh kembang, (d) Penerapan kebun gizi menggunakan wall planter bag

Gerakan sukses ASI eksklusif merupakan salah satu kegiatan Srikandi PMBA ini, kegiatan sukses ASI esklusif meliputi pendampingan persiapan laktasi pada ibu hamil trimester 3, sehingga ibu hamil akan mempunai pengetahuan untuk mempersiapkan proses menyusui. Menyusui merupakan hal yang fisiologis, namun memerlukan edukasi dan dukungan sejak ibu hamil agar saat mulai menyusui ibu tidak lagi mengalami kendala dalam pemberian ASI (Luthfiyati \& Widaryanti, 2019). Pada kehamilan trimester 3 ibu hamil di sarankan melakukan kontak dengan konselor ASI untuk mendapatkan informasi mengenai anatomi payudara, mekanisme produksi ASI, keuntungan menyusui, manfaat ASI, dampak susu formula, perawatan payudara selama hamil, proses Inisiasi Menyusu Dini (IMD), serta teori mengenai posisi dan perlekatan bayi saat menyusu (Rahayu Widaryanti, 2019c).

Pada saat ibu melahirkan diharapkan memilih pelayanan kesehatan yang pro ASI sehingga akan mendapatkan bimbingan mengenai laktasi secara optimal. Pada saat ibu sudah pulang dari fasilitas kesehatan peran Srikandi PMBA yaitu mendampingi ibu agar sukses menyusui hingga 2 tahun. Pada masa pandemi COVID-19 pemberian ASI menjadi pilihan yang tepat sekalipun pada ibu yang terkonfirmasi positif COVID-19 (Williams et al., 2020). Beberapa penelitian menunjukkan bahwa pada ibu yang terkonfirmasi positif COVID-19 ASI maupun cairan air ketuban tidak mengandung virus tersebut sehingga belum ada bukti yang mendukung penularan virus dari ibu dan anak melalui ASI (El-Gilany, 2020).

ASI mengandung antibody yang dapat meningkatkan daya tahan tubuh bayi sehingga tidak mudah sakit (Ranganathan, Maroof, \& Chhabra, 2020). Bayi yang diberikan ASI menjadi jarang sakit dan tidak memerlukan pengobatan. Selain itu pemberian ASI dapat menekan pengeluaran keluarga, dimana pada kondisi sekarang banyak keluarrga yang mengalami penurunan pendapatan yang diakibatkan karena kebijakan pembatasan social beskala besar untuk pencegahan penularan virus (Pradana \& Casman, 2020).

Tugas lain Srikandi PMBA adalah memberikan pendampingan pada masyarakat yang memiliki balita dengan usia diatas 6 bulan yaitu periode pemberian makanan pendamping ASI (MP ASI). Pemberian MP ASI yang tepat dapat membantu mencegah stunting, hasil penelitian yang dilakukan di Sleman tahun 2019 diperoleh data bahwa $47 \%$ balita yang mengalami stunting dikarenakan praktik pemberian PMBA yang tidak tepat. Sebagian besar ibu mulai memberikan MP ASI pada anaknya mulai usia 5 bulan, makanan yang sering diberikan adalah pisang lumat dan bubur beras. Pemberian MP ASI harus memperhatikan Angka Kecukupan Gizi (AKG) yang di anjurkan berdasarkan kelompok umur dan tekstur makanan yang 
sesuai perkembangan usia balita. terkadang orang tua memberikan MP ASI sebelum usia 6 bulan, padahal usia tersebut kemampuan pencernaan bayi belum siap menerima makanan tambahan akibatnya banyak yang mengalami diare (Widaryanti, 2019).

Edukasi makanan pendamping ASI menu empat bintang dengan bahan lokal dapat mencegah masalah gizi pada bayi dan balita. Penelitian yang diakukan Rahayu Widaryanti (2019) sebanyak 70,76 \% balita stunting tidak mendapatkan MP ASI yang sesuai. Makanan pendamping ASI yang dibuat sendiri di rumah lebih terjamin kebersihannya dan komposisi bahan makanannya. Upaya pengoptimalan bahan lokal dalam membuat MP ASI bertujuan untuk menghemat biaya pengeluaran keluarga yang mengalami penurunan pada masa pandemi Covis-19. Ibu tidak perlu menyiapkan anggaran khusus untuk membuat MP ASI karena prinsipnya adalah menu yang dimakan keluarga pada hari itu sama dengan menu untuk membuat MP ASI. (Rahayu Widaryanti, 2020)

Untuk memantau status gizi bayi dan balita Srikandi PMBA juga dibekali tentang cara melakukan pengukuran antropometri serta pemantauan tumbuh kembang menggunakan Kuisioner Pra Skrining Perkembangan (KPSP) yang di dampingi oleh tim pengabdi. Kemampuan melakukan skrining tumbuh kembang menggunaan KPSP penting dimiliki oleh kader, karena kader merupakan garda terdepan dalam kegiatan kesehatan di posyandu. Selain itu kader merupakan orang yang setiap hari berinteraksi dengan masyarakat sehingga mempermudah dalam melakukan pemantauan (Purnami, 2020). Kemampuan kader dalam mengkur antropometri terutama pada pengukuran tinggi badan/panjang badan pada bayi dan balita masih perlu ditingkatkan. Dari hasil pengamatan pengabdi pemeriksaan panjang badan masih menggunakan metlin sehingga hasil yang diperoleh menjadi kurang valid. Pemeriksaan panjang badan sebaiknya menggunakan alat yang sesuai standar yaitu infantometer.

Untuk mendukung kecukupan nutrisi keluarga Srikandi PMBA mencanangkan program kebun gizi, adapun kegiatannya meliputi optimalisasi lahan pekarangan untuk menanam sayur. Bagi warga yang memiliki lahan pekarangan terbatas maka praktik kebun gizi dilakukan menggunakan wall planter bag atau pot kantong tanaman dinding. Dengan upaya penanaman sayuran di pekarangan rumah diharapkan dapat membantu memenuhi kebutuhan nutrisi keluarga terebih lagi saat pandemi COVID-19 (Zati, Murdhiani, \& Rosalina, 2020). Program kebun gizi dapat mengurangi pengeluaran belanja keluarga, dimana dalam masa pandemik banyak keluarga yang mengalami penurunan pendapatan finansial akibat pembatasan sosial berskala besar (Pradana \& Casman, 2020).

\section{KESIMPULAN}

Kegiatan pengabdian kepada masyrakat ini diakukan di Dusun Sentikan, Karangnongko, Tirtomartani, Kalasan, Sleman, DIY pada bulan September sampai dengan November 2020. Kegiatan dimulai dengan sosialisasi program serta pelatihan dan pembentukan Srikandi PMBA yang diikuti oleh 8 kader posyandu. Dari hasil pre dan post test terdapat peningkatan pengetahuan tentang pemberian makan bayi dan anak serta tehnik komunikasi dan konseling sebanyak 45 point. Kegiatan selanjutnya yaitu pemantauan tumbh kembang menggunakan KPSP yang diikuti oleh 8 balita dengan hasil $75 \%$ sesuai dan 25 \% meragukan. Selain pemeriksaan tumbuh kembang Srikandi PMBA juga melakukan edukasi PMBA dan menjadi motor gerakan kebun gizi dengan cara memanfaatkan lahan pekarangan untuk menanam sayur untuk memenhi kebuthan ruumah tangga.

\section{UCAPAN TERIMA KASIH}

Penulis mengucapkan terima kasih kepada Universitas yang telah memberi dukungan terhadap pengabdian ini.

\section{DAFTAR PUSTAKA}

Dinkes. (2020). Profil Kesehatan Kabupaten Sleman 2020. Sleman

El-Gilany, A. (2020). COVID-19 and Breastfeeding. Asp Biomed Clin Case Rep, 3(2), 102-105. doi:https://doi.org/10.36502/2020/ASJBCCR.6194

Indonesia, K. K. R. (2020). Profil Kesehatan Indonesia 2019. Jakarta: Kementrian Kesehatan Republik Indonesia 
Kemenkes. (2018). Situasi Balita Pendek (Stunting di Indonesia). Buletin Jendela Data Dan Informasi Kesehatan.

Luthfiyati, Y., \& Widaryanti, R. (2019). Persiapan Laktasi pada Ibu Hamil untuk Mencegah Masalah dalam Pemberian ASI Eksklusif di PMB Istri Yuliani Sleman. Paper presented at the Prosiding Seminar Nasional Multidisiplin Ilmu.

Pradana, A., \& Casman. (2020). Pengaruh Kebijakan Social Distancing pada Wabah COVID-19 terhadap Kelompok Rentan di Indonesia. Jurnal Kebijakan Kesehatan Indonesia: JKKI, 9(2), 6167. doi:https://doi.org/10.22146/jkki.55575

Purnami, L. A. (2020). Kuesioner Pra Skrining Perkembangan (KPSP) Sebagai Penilaian Tumbuh Kembang Balita: Pelatihan Kader Desa Girimas. Jurnal Pengabdian Masyarakat Kesehatan, 6(2), 71-74.

Rahmawati, S. M., Madanijah, S., Anwar, F., \& Kolopaking, R. J. G. I. (2019). Konseling Oleh Kadeer Posyyaandu Meningkatkan Praktik Ibu dalam Praktik Pemberian Makan Bayi dan AAnak Usia 6-24 Bulan di Desa Pagelaran, Kecamatan Ciomas, Bogor, Indonesia. 42(1), 11-22.

Ranganathan, R., Maroof, K. A., \& Chhabra, P. J. I. J. o. C. H. (2020). Antenatal care, care at birth, and breastfeeding during the Coronavirus (COVID-19) pandemic. 32(1), 17-20.

Sakti, E. S. (2018). Meyusui Sebagai dasar kehidupan Tema Pekan ASI Sedunia 1-7 Agustus 2018. Jakarta: Pusat Data dan Informasi

Subagyo, W. J. J. K. S. (2010). Kemampuan Kader dan Partisipasi Masyarakat pada Pelaksanaan Program Posyandu di Karangpucung Purwokerto Selatan. Jurnal Keperawatan Soedirman, 5(2), 74-79.

Widaryanti, R. (2019a). Hambatan Program Pemberian Makan Bayi dan Anak. Paper presented at the Prosiding Seminar Nasional Multidisiplin Ilmu.

Widaryanti, R. (2019b). Knowledge Community Health Volunteer (chv) of Infant and Young Child Feeding (IYCF) in Disaster Conditions Proceding 1 st International Respati Health Conference "Healthy and Active Ageing".

Widaryanti, R. (2019). Makanan Pendamping ASI Menurunkan Kejadian Stunting pada Balita Kabupaten Sleman. Jurnal Ilmiah Kesehatan Ar-Rum Salatiga, 3(2). doi:https://doi.org/10.36409/jika.v3i2.35

Widaryanti, R. (2019c). Pemberian Makan Bayi dan Anak. Yogyakarta: Deepublish.

Widaryanti, R. (2020). Edukasi Mp ASI 4* Home Made Dengan Bahan Pangan Lokal. Jurnal Pengabdian Dharma Bakti, 3(2), 1-7.

Widaryanti, R., \& Rahmuniyati, M. E. (2019). Evaluasi Pasca Pelatihan Pemberian Makan Bayi dan Anak (PMBA) pada Kader Posyandu Terhadap Peningkatan Status Gizi Bayi dan Balita. Jurnal Formil (Forum Ilmiah) Kesmas Respati, 4(2). doi:10.35842/formil.v4i2.273

Williams, J., Namazova-Baranova, L., Weber, M., Vural, M., Mestrovic, J., Carrasco-Sanz, A., . . . Pettoello-Mantovani, M. (2020). The importance of continuing breastfeeding during COVID19: in support to the WHO statement on breastfeeding during the pandemic. The Journal of Pediatrics. doi:https://doi.org/10.1016/j.jpeds.2020.05.009

Zati, M. R., Murdhiani, M., \& Rosalina, D. (2020). Pelatihan Budidaya Metode Veertical Garden dalam Menghadapi Masa Pandemi COVID 19. SELAPARANG Jurnal Pengabdian Masyarakat Berkemajuan, 4(1), 306-310. 